\title{
A quantitative analysis of Iranian EFL learners' sources of written errors
}

Rostami Abusaeedi, Ali Asghar

Shahid Bahonar University of Kerman, Iran (rostamiabu110@yahoo.com)

Boroomand, Faezeh $\$

Shahid Bahonar University of Kerman, Iran (faezeh_boroomand@yahoo.com)

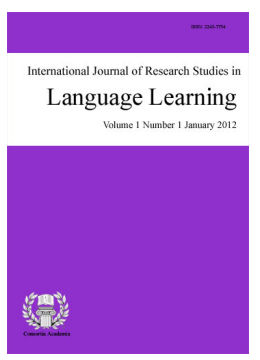

ISSN: $2243-7754$

\section{Abstract}

Error Analysis (EA), as a diagnostic tool, contributes to language teaching and learning by answering some questions and proposing solutions regarding different aspects of language pedagogy. The present study conducted on 100 Iranian advanced EFL learners' written errors (50 male learners \& 50 female learners), presents different classifications and subdivisions of error sources. Analysis of the sources of errors committed by the two groups of male and female learners shows that the errors mostly result from partial learning and imperfect mastery of the target language (intralingual) while transfer from mother tongue (interlingual) accounts for a small proportion of errors. It also reveals that although there are more errors in female learners' written productions, the hierarchy of different sources of errors in the two groups of male and female learners is the same.

Keywords: error analysis; sources of errors; written production; EFL; ESL 


\section{A quantitative analysis of Iranian EFL learners' sources of written errors}

\section{Introduction}

EA is a non-stop area of research (Dessouky, 1990), and will remain so because people will commit errors as long as they participate in language learning process (Mahmoud, 2011). Error Analysis, as a diagnostic tool, contributes to language teaching and learning by answering some questions and proposing solutions regarding different aspects of language pedagogy. Analyzing language learners' errors systematically makes it possible to determine the problematic areas which need reinforcement in teaching (Corder, 1967). Analyzing EFL learners' errors in their written performance can be a great help for teachers to become aware of the types and sources of these errors to employ more efficient teaching methods and techniques so that EFL learners can acquire English writing better and enhance their writing competence.

Sources of language learners' errors tell us why, when, where and how the errors are committed. Without detecting and identifying sources of errors, treatment of EFL learners' errors is impossible. Among different error sources, interlingual and intralingual factors have been considered as two major sources of EFL learners' errors, but researchers haven't reached a unanimous contention on the key role of one of these two error sources with respect to EFL learners' error commitment. The main concern of the present study is to identify and analyze the sources of errors extracted from Iranian advanced EFL learners' writing papers. Furthermore, the frequencies of sources of errors committed by these learners are contrasted according to their gender. The obtained results are expected to be of value to EFL teachers, syllabus designers and researchers. In the end, Mentioning the limitations of the study, several suggestions are presented for more researches.

\section{Literature review}

\subsection{Error Analysis (EA)}

In the early 1950's the notion of language as a system, and more importantly, the notion of second language acquisition as the meeting of two language systems gained more acceptance and linguists began to regard errors as evidence of language transfer. It was the time when Contrastive Analysis (CA) emerged. The status of CA as a psychological approach to the investigation of the second language process became unpopular for some reasons and CA gradually lost its validity. Strong criticisms of CA showed that it was not as useful as it claimed to be. CA strongly emphasized that the notion of difficulty was equated with the degree of errors. Namely, the more L2 learners made errors in their acquisition of L2 the more it was assumed to be difficult and consequently the more the target and native languages were different. Another pitfall of CA was its inability in identifying sources of difficulty other than the learners' L1. Additionally CA didn't contribute to language pedagogy effectively.

Because of the drawbacks of CA, in late 1960s and early 1970s, the specialists' attitudes towards errors changed gradually, and the emphasis shifted from the product to the underlying process with respect to ESL/EFL learners' error commitment. The students' errors were not regarded as problems anymore but as normal and inevitable events in language learning process which could contribute to the understanding of the strategies employed by first or second language learners. The first argument for significance of learners' errors was made by Corder in 1967. Corder (1967) mentioned that errors are evidence of the learners' in-built syllabus which show how L1 and L2 learners develop an independent system of language. In fact, language learners make their own language which is different from their L1 and L2 and has its own set of rules. The term interlanguage was coined by Selinker (1972) to refer to this linguistic system. Keshavarz (1999) divided EA into two branches: theoretical and applied. Theoretical error analysis is about the processes of first and second language learning and applied error analysis is concerned with pedagogical issues such as organizing remedial courses and devising 
A quantitative analysis of Iranian EFL learners' sources of written errors

appropriate materials and teaching strategies based on EA findings (ibid).

In the last decades, many studies have been conducted on ESL/EFL learners' sources of errors. Kim (2001) examined the sources and nature of learners' errors in their writing samples. The results revealed that most of the errors were intralingual while a small proportion of errors could be attributed to L1 interference. Ghafar Samar and Seyyed Rezaie (2006) carried out an EA on errors made by Iranian learners of English in their written productions. The results showed that negative transfer accounted for only 30\% of all the errors. Wee (2009) analyzed Malaysian ESL learners' written verb-form errors and found that these errors occurred due to an interaction of interlingual and intralingual factors. In their study, Behjat and Sadighi (2010) found that transfer of the L1 grammar operated differently at different stages in regard to certain aspects of grammar. Al-Khresheh (2010) investigated the interference of L1 (Arabic) syntactic structures on L2 (English) syntactic structures among Jordanian learners of English and found out that interlingual errors committed by the learners were due to differences between L1 and L2 as well as transfer from two different varieties of Arabic. Nayernia (2011) analyzed 30 erroneous sentences of some Iranian EFL learners. The results showed that the majority of the errors were intralingual which should be traced to the target language system. Abbasi and Karimnia (2011) investigated a number of grammatical errors committed by Iranian university students in their translation. The findings revealed that most of the errors were interlingual, indicating the influence of students' mother tongue.

Alhaysony (2012) carried out an analysis on errors committed by Saudi female EFL learners in their use of articles in their written samples. The result of the study indicated that L1 interference strongly affected the process of second language acquisition of the articles, having negative effect on the learning process. Ridha (2012) examined EFL college students' errors and concluded that most of the learners relied on their mother tongue in expressing their ideas and their major errors could be due to the L1 transfer. Sattari (2012) analyzed grammatical errors in Persian English learners' compositions and exam papers. The results of the study showed that a great number of persistent errors made by these learners at elementary levels could be traced to the influence of their mother tongue. Rahmani and Bagherzadeh Kasmani (2012), in their study on errors made by Persian and Kurdish speaking students majoring in English Translation, found that interference from learners' mother tongue was the main cause of errors. Sabzalipour (2012) conducted an analysis on advanced EFL students' errors in their translation from Persian to English. The results showed that major errors were intralingual. Kafipour and Khojasteh (2012) analyzed students' errors in their writings and found out that the majority of the errors were developmental while interlingual errors constituted the lowest number of errors.

Rabieefar and Askarzadeh Torghabeh (2012) analyzed Iranian EFL learners' written errors at elementary and intermediate levels. They found that the proportion of learners' interlingual and intralingual errors were different at different proficiency levels. Al-Shormani (2012) examined the sources of syntactic errors committed by Yemeni Arabic-speaking university learners of English. The results of the analysis showed that L2-Influence, as the main source of syntactic errors, scored (63.73\%), which was followed by L1-transfer (27.90\%), L1 and L2 (6.99\%), and unrecognized source (1.38\%) respectively. Reishaan (2013) analyzed Iraqi advanced EFL learners' written errors in use of tenses and found out that these errors were basically related to L1 interference. Barzegar (2013) carried out an analysis on errors committed by Persian learners of English at intermediate levels. The results of the study indicated that, with regard to Sources of Errors, the majority of errors were Intralingual. Ramezani (2013) investigated pre-intermediate and advanced learners' sources of syntactic errors in their oral performance. The findings of her study revealed that there were significant differences between the intermediate and advanced learners' sources of errors. The intermediate learners mostly committed interlingual errors while most advanced learners committed intralingual errors.

\subsection{Sources of errors}

Careful and clear understanding of the sources of language learners' errors plays an important role in EA studies. As there are many descriptions for different types of errors, the mechanisms which lead to committing errors are various. Sanal (2007) believed that these mechanisms needed to be fully understood by linguists in 
order to arrive at effective remedial measures.

Dulay and Burt (1972) categorized L2 learners' errors which they preferred to call goofs as follows: interference-like goofs, L1-developmental goofs, ambiguous goofs (either interference-Like or L1-developmental goofs), unique goofs (neither interference-like nor L1-developmental goofs). Selinker (1972) suggested five processes leading to errors: (1) language transfer (negative transfer which hinders the learning of second language. Language transfer involves pronunciation, word order and grammar, semantic transfer, transfer in writing, pragmatic transfer and culture transfer); (2) transfer of training (items resulting from particular approaches used in training); (3) strategies of second language learning (identifiable approaches by the learner to develop linguistic and sociolinguistic competence in the target language); (4) strategies of second language communication (identifiable approaches by the learner to communicate with native speakers of target language); (5) overgeneralization (overgeneralization of TL rules and semantic features without making the appropriate exception).

Corder (1974) distinguished three types of errors based on their sources: interlingual, intralingual and teacher-induced errors. According to him interlingual errors are caused by L1 interference; intralingual errors are caused by the learner's generalizing and overgeneralizing particular rules and teaching-induced errors are caused by faulty teaching techniques. Brown (1980) identified four sources of error: (1) Interlingual Transfer (2) Intralingual Transfer (3) Context of Learning (4) Communication Strategies. In broad terms Faerch et al. (1984), considered two main causes which result from both internal and external factors. Internal factors deal with the motivation of the learners, the capacity they have for studying, and their attitude to the target language and culture. External factors tend to be teaching methods or teaching materials which induce errors.

Taylor (1986) identified sources of errors as psycholinguistic, sociolinguistic, epistemic and the ones which reside in the discourse structure. Psycholinguistic sources concern the nature of the L2 knowledge system and the difficulties learners have in using it in production. Sociolinguistic sources involve such matters as the learners' ability to adjust their language in accordance with the social context. Epistemic sources concern the learners' lack of world knowledge, while discourse sources involve problems in the organization of information into a coherent text. Rostami Abusaeedi and Shariati (2003), based on the results of their study on Iranian EFL learners, classified the sources of errors as follows: transfer of training, interference from L1, developmental and intralingual errors, anxiety, lack of an English environment, lack of motivation, bilingual dictionaries, lack of correction understanding, transfer of stylistic and cultural elements, varieties of English, and students' poor knowledge of English. Tajadini Rabori (2006) classified error sources into three types: mono-source, bi-source (inter-intra lingual), and ambiguous errors.

\section{Theoretical framework of the study}

Corder (1974) suggested five steps in an error analysis: (1) collection of a sample of learner language (2) identification of errors (3) description of errors (4) explanation of errors (5) evaluation of errors. In most of EA studies, researchers have classified learners' sources of errors into two domains of interlingual and intralingual (Shreshta, 1979; Erdogan, 2005; Sabzalipour, 2012). Arranging errors in two groups of interlingual errors and intralingual errors can clarify the processes and strategies used by learners which lead to errors (Catalán, 1997). In the present study the sources of errors are classified into three categories: interlingual, intralingual and bi-source. Interlingual errors are just regarded from the view point of transfer of grammatical rules and intralingual errors are categorized into three groups: overgeneralization of language rules, incomplete application of language rules and faulty categorization.

\subsection{Interlingual Errors}

Interlingual errors are those errors which result from the transfer of learner's native language rules into the TL. Namely, errors in this category are largely caused by the influence of learner's L1 on the acquisition of an 
L2. Interlingual errors are also known as transfer errors, interference errors, interlanguage errors and language-specific errors (Catalán, 1997).

\subsection{Intralingual errors}

Intralingual errors result from faulty or partial learning of the target language rather than language transfer. Namely, learners make mistakes because they do not know the target language very well, and have difficulties in using the target language. Intralingual errors are classified into different categories by different researchers, although there are not always clear boundaries between these categories, and they overlap each other. Richards (1971) classified intralingual errors into four categories: (1) overgeneralization (the learner creates a deviant structure on the basis of other structures in the target language); (2) ignorance of rule restrictions (the learner applies rules to the context where they are not applicable); (3) incomplete application of rules (the learner fails to use a fully developed structure); (4) false concepts hypothesized (the learner does not fully understand a distinction in the target language). Intralingual errors have other subcategories such as hyperextension and faulty categorization (Keshavarz, 1999 cited in Ramezani, 2013). Hyperextension refers to the extension of a rule to areas where it is not applicable while, faulty categorization refers to the wrong classification of the target language forms.

\subsection{Bi-Source errors}

Some errors are caused by both factors of L1 and L2. Tajadini Rabori (2006) called this type of errors Bi-source errors.

\subsection{Research questions}

The present study tries to seek answers to the following questions:

$>$ Are there any significant differences between the frequencies of different sources of errors in written productions of advanced EFL male/female learners? (interlingual, intralingual, bi-source).

$>$ Are there any significant differences between the frequencies of interlingual errors, caused by transfer of grammatical rules, in written productions of advanced EFL male/female learners?

$>$ Are there any significant differences between the frequencies of intralingual errors committed by advanced EFL male/female learners in their writing papers? (overgeneralization of language rules, incomplete application of language rules, faulty categorization).

\subsection{Significance of the study}

Improving EFL learners' writing competence requires treatment of their written errors. It is possible to treat EFL learners' written errors only if the sources of these errors are detected and identified. Regarding the previous studies done on EFL learners' errors, as mentioned in the literature review, with respect to EFL learners' error commitment, researchers haven't reached a unanimous contention on the key role of one of the two major error sources (interlingual or intralingual). In other words, some researchers consider interlingual factors as the main source of EFL learners' errors while others believe that errors mostly occur because of intralingual factors.

Gender is an influential variable in nearly all social phenomena including language, so it can be a considerable source of variation among language learners, and teachers must consider its impact on language learning (Yazdani, \& Ghafar Samar, 2010). Having enough knowledge of gender differences is a need for educators to achieve pedagogical goals. Although the issue of gender differences has been considered in the context of second or foreign language learning and teaching, few studies on the relationship between gender and EFL learners' written errors have been carried out and the impact of learners' gender, as a constant learner variable, on the rate, types and sources of errors has not received much attention. The present study examines 
Rostami Abusaeedi, A. A. \& Boroomand, F.

Iranian advanced EFL learners' sources of errors according to their gender.

\section{Methodology}

\subsection{Participants}

Advanced EFL learners who took part in the present study were 100 in number (50 male students \& 50 female students). These learners had studied English for years in an English Institute in Kerman (a city in south east of Iran) with the same syllabus, material, and teaching methodology. They were all Iranian and native speakers of Persian. They were chosen by random sampling. Their writing papers were collected, corrected and analyzed by the researchers.

\subsection{Instruments}

A total of 100 learners' writing papers were gathered randomly. These writing papers had been written by advanced EFL learners (50 male students and 50 female students) on the same topic.

\subsection{Procedures}

Considering gender as one of the variables in the study, the same number of male and female learners took part in the study. Among advanced classes in an English institute in Kerman, a city in south east of Iran, the researchers randomly selected four classes with male EFL learners and four classes with female EFL learners. Each of these classes included 25 learners who were studying English at advanced levels. These learners (100 male learners and 100 female learners) wrote writing papers on one subject. Therefore, a total of 200 writing papers were collected. The papers were then numbered by the researchers from 1 to 100 in each group of male and female learners, and then the ones with odd numbers were selected and corrected. The errors extracted from 100 writing papers (50 papers written by male learners and 50 papers written by female learners) were identified, described and categorized according to their sources, and at last they were analyzed by statistical tests.

As mentioned before, in the present study, the sources of errors were classified into three categories: interlingual, intralingual and bi-source. Interlingual errors were just regarded from the view point of transfer of grammatical rules and intralingual errors were categorized into three groups: overgeneralization of language rules, incomplete application of language rules and faulty categorization. Chi-Square test investigated if there were any significant differences among the frequencies of different subdivisions in each category and then the sources of errors in the two groups of male and female learners were compared by use of Pearson Chi-Square test (Cross-Tab).

\section{Results}

\subsection{Chi-Square test}

Categorical data, as a type of data which can be counted and divided into categories can be analyzed by Chi-Square. Chi-Square test is used to investigate whether distributions of categorical variables differ from one another. In the present study, Chi-Square test was used to reveal the distributions of subdivisions of different sources of errors committed by advanced learners in their writing papers. According to table 1, among 356 errors committed by advanced male learners, 55 errors $(15.4 \%)$ were caused by interlingual factors, 270 errors $(75.8 \%)$ were caused by intralingual factors, and 31 errors $(8.7 \%)$ were caused by bi-source factors. Based on chi-square test, p-value is 0 which is less than the significance level $(\alpha=0.05)$; Therefore, there are significant differences among the frequencies of different sources of male learners' errors. Considering the percentages of different sources of errors committed by advanced male learners, it can be concluded that intralingual and bi-source 
A quantitative analysis of Iranian EFL learners' sources of written errors

factors were respectively the most and the least sources of advanced male learners' errors.

Table 1

Advanced EFL male learners' sources of errors in their writing papers

\begin{tabular}{|c|c|c|c|c|c|}
\hline $\begin{array}{c}\text { Males' } \\
\text { Sources } \\
\text { of errors }\end{array}$ & Frequency & percent & $\begin{array}{c}\text { Chi-Square } \\
\text { (a) }\end{array}$ & df & $\begin{array}{c}\text { Asymp. Sig } \\
\text { (p-value) }\end{array}$ \\
\hline Inter & 55 & 15.4 & & & \\
\hline Intra & 270 & 75.8 & 291.916 & 2 & 0.000 \\
\hline Bis & 31 & 8.7 & & & \\
\hline Total & 356 & 100.0 & & & \\
\hline
\end{tabular}

Table 2

Advanced EFL female learners' sources of errors in their writing papers

\begin{tabular}{|c|c|c|c|c|c|}
\hline $\begin{array}{l}\text { Females' } \\
\text { Sources } \\
\text { of errors }\end{array}$ & Frequency & percent & $\begin{array}{c}\text { Chi-Square } \\
\text { (a) }\end{array}$ & df & $\begin{array}{c}\text { Asymp. Sig } \\
\text { (p-value) }\end{array}$ \\
\hline Inter & 78 & 13.5 & & & \\
\hline Intra & 454 & 78.8 & 539.292 & 2 & 0.000 \\
\hline Bis & 44 & 7.6 & & & \\
\hline Total & 576 & 100.0 & & & \\
\hline
\end{tabular}

According to table 2, among 576 errors committed by advanced female learners, 78 errors (13.5\%) were caused by interlingual factors, 454 errors $(78.8 \%)$ were caused by intralingual factors, and 44 errors $(7.6 \%)$ were caused by bi-source factors. Based on chi-square test, $\mathrm{p}$-value is 0 which is less than the significance level ( $\alpha$ $=0.05$ ); Therefore there are significant differences among the frequencies of different sources of female learners' errors. Considering the percentages of different sources of errors committed by advanced female learners, it can be concluded that intralingual and bi-source factors were respectively the most and the least sources of advanced female learners' errors.

Table 3

Advanced EFL male learners' written errors caused by intralingual factors

\begin{tabular}{|c|c|c|c|c|c|}
\hline $\begin{array}{c}\text { Males' } \\
\text { intralingual } \\
\text { errors } \\
\end{array}$ & Frequency & percent & $\begin{array}{c}\text { Chi-Square } \\
\text { (a) }\end{array}$ & df & $\begin{array}{c}\text { Asymp. Sig } \\
\text { (p-value) }\end{array}$ \\
\hline Over & 62 & 44.0 & & & \\
\hline IncApp & 72 & 51.1 & 52.128 & 2 & 0.000 \\
\hline FauCat & 7 & 5.0 & & & \\
\hline Total & 141 & 100.0 & & & \\
\hline
\end{tabular}

According to table 3, among 141 intralingual errors committed by advanced male learners, 62 errors (44\%) were caused by overgeneralization of language rules, 72 errors $(51.1 \%)$ were caused by incomplete application of language rules, and 7 errors (5\%) were caused by faulty categorization. Based on chi-Square test, p-value is 0 which is less than the significance level $(\alpha=0.05)$; Therefore there are meaningful differences among the frequencies of different types of intralingual errors in advanced male learners' writing papers. Considering the percentages of different types of intralingual errors committed by advanced male learners, it can be concluded that incomplete application of language rules and faulty categorization were respectively the most and the least types of intralingual errors committed in advanced male learners' writing papers. 
Rostami Abusaeedi, A. A. \& Boroomand, F.

\section{Table 4}

Advanced EFL female learners' written errors caused by intralingual factors

\begin{tabular}{|c|c|c|c|c|c|}
\hline $\begin{array}{c}\text { Females' } \\
\text { intralingual } \\
\text { errors }\end{array}$ & Frequency & percent & $\begin{array}{l}\text { Chi-Square } \\
\text { (a) }\end{array}$ & df & $\begin{array}{c}\text { Asymp. Sig } \\
\text { (p-value) }\end{array}$ \\
\hline Over & 119 & 40.2 & & & \\
\hline IncApp & 167 & 56.4 & 131.196 & 2 & 0.000 \\
\hline FauCat & 10 & 3.4 & & & \\
\hline Total & 296 & 100.0 & & & \\
\hline
\end{tabular}

According to table 4, among 296 intralingual errors committed by advanced female learners, 119 errors (40.2\%) were caused by overgeneralization of language rules, 167 errors (56.4\%) were caused by incomplete application of language rules, and 10 errors (3.4\%) were caused by faulty categorization. Based on chi-Square test, $\mathrm{p}$-value is 0 which is less than the significance level $(\alpha=0.05)$; Therefore there are meaningful differences among the frequencies of different types of intralingual errors in advanced female learners' writing papers. Considering the percentages of different types of intralingual errors committed by advanced female learners, it can be concluded that incomplete application of language rules and faulty categorization were respectively the most and the least types of intralingual errors committed in advanced female learners' writing papers.

As mentioned before, in the present study just one type of interlingual errors (transfer of grammatical rules) were analyzed in advanced male and female learners' writing papers; Therefore, gender is the only variable in research question 2 and that's why chi-square test was used to contrast errors caused by transfer of grammatical rules in the two groups of male and female learners' writing papers.

\section{Table 5}

Interlingual errors caused by transfer of grammatical rules in advanced EFL malelfemale learners' writing papers

\begin{tabular}{lccccc}
\hline $\begin{array}{l}\text { Transfer of } \\
\text { grammatical } \\
\text { rules }\end{array}$ & Frequency & percent & $\begin{array}{c}\text { Chi-Square } \\
\text { (a) }\end{array}$ & df & $\begin{array}{c}\text { Asymp. Sig } \\
\text { (p-value) }\end{array}$ \\
\hline $\mathrm{M}$ & 60 & 43.8 & & & 0.146 \\
$\mathrm{~F}$ & 77 & 56.2 & 2.109 & 1 & \\
\hline Total & 137 & 100.0 & &
\end{tabular}

According to table 5, among 137 errors caused by transfer of grammatical rules, in advanced learners' writing papers, 60 errors $(43.8 \%)$ were committed by advanced male learners and 77 errors (56.2\%) were committed by female learners. Based on chi-square test, p-value is 0.146 which is more than the significance level $(\alpha=0.05)$; Therefore there aren't any significant differences between the frequencies of errors caused by transfer of grammatical rules in the two groups of male and female learners.

\subsection{Pearson Chi-Square test (Cross-Tab)}

Pearson Chi-Square test was used to contrast the frequencies of different sources of written errors in the two groups of advanced EFL male and female learners, and find out if there were any significant differences between these groups regarding the frequencies of their sources of written errors. According to table 6, based on Pearson Chi-Square test, $\mathrm{p}$-value is 0.57 which is more than the significance level $(\alpha=0.05)$; Therefore, there aren't any significant differences between the two groups of advanced male and female learners regarding their sources of errors. However, contrasting the frequencies of different sources of errors in the two groups of male and female learners shows that regarding all sorts of error sources, the frequencies of female learners' error commitment are higher. 
A quantitative analysis of Iranian EFL learners' sources of written errors

Table 6

Contrasting advanced EFL male and female learners' sources of errors in their writing papers

\begin{tabular}{|c|c|c|c|c|c|c|}
\hline $\begin{array}{l}\text { Sources } \\
\text { of errors }\end{array}$ & Male & Female & Total & $\begin{array}{c}\text { Pearson } \\
\text { Chi-Square }\end{array}$ & df & $\begin{array}{c}\text { Asymp. Sig } \\
\text { (p-value) }\end{array}$ \\
\hline Inter & 55 & 78 & 133 & & & \\
\hline Intra & 270 & 454 & 724 & $1.125(\mathrm{a})$ & 2 & 0.57 \\
\hline Bis & 31 & 44 & 75 & & & \\
\hline Total & 356 & 576 & 932 & & & \\
\hline
\end{tabular}

Table 7

Contrasting advanced EFL male and female learners' intralingual errors in their writing papers

\begin{tabular}{|c|c|c|c|c|c|c|}
\hline $\begin{array}{c}\text { intralingual } \\
\text { errors }\end{array}$ & Male & Female & Total & $\begin{array}{l}\text { Pearson } \\
\text { Chi-Square }\end{array}$ & $\mathrm{df}$ & $\begin{array}{l}\text { Asymp. Sig. } \\
\text { (p-value) }\end{array}$ \\
\hline Over & 62 & 119 & 181 & & & \\
\hline IncApp & 72 & 167 & 239 & $1.446(\mathrm{a})$ & 2 & 0.485 \\
\hline FauCat & 7 & 10 & 17 & & & \\
\hline Total & 141 & 296 & 437 & & & \\
\hline
\end{tabular}

According to table 7, based on Pearson Chi-Square test, p-value is 0.485 which is more than the significance level $(\alpha=0.05)$; Therefore, there aren't any significant differences between the two groups of advanced male and female learners, regarding their intralingual errors. However, contrasting the frequencies of different sorts of intralingual errors in the two groups of male and female learners shows that regarding all sorts of intralingual errors, the frequencies of female learners' error commitment are higher.

\section{Discussion and conclusion}

In the field of Error Analysis, many sources of errors have been identified which extend beyond the scope of interlingual errors. In other words, although interference from mother tongue is considered as a source of errors, it is by no means the only source (Sheikhzadeh \& Gheichi, 2011). Results of the present study showed that intralingual factors had the most impact on advanced EFL learners' error commitment. In other words, advanced EFL learners' errors aren't mostly rooted in their mother tongue (Persian), but they mainly result from partial learning and incomplete mastery of the target language (English). This is consistent with the results of the studies made by Kim (2001), Ghafar Samar and Seyyed Rezaie (2006), Nayernia (2011), Sabzalipour (2012), Kafipour and Khojasteh (2012), Al-Shormani (2012), Barzegar (2013), and Ramezani (2013).

Dan (2007), based on his EA study, stated that advanced learners make intralingual errors twice more than interlingual errors. Reasoning this fact, Selinker (1972) stated that a foreign language learner in the beginning stages develops an IL which is close to her native competence; however, an advanced learner's IL is closer to the TL competence. Brown (1994) also claimed that at the beginning levels, errors mostly occur due to negative transfer but as learners improve in target language, intralingual errors overcome interlingual errors. As mentioned before, incomplete application of language rules (undergeneralization) and overgeneralization of language rules were respectively the major intralingual factors causing errors in advanced learners' written productions, while faulty categorization was the minor factor. Although advanced language learners are at a closer stage to the TL, incomplete application of language rules usually happens because of not using a language rule with its correct and complete form. As Taylor (1975) mentioned, overgeneralization of language rules by language learners is an attempt to systematize and regularize the complex structures in the TL. Errors caused by transfer of grammatical rules were the only type of interlingual errors analyzed in this study, and the distribution of error frequencies in the two groups of male and female learners revealed no significant differences regarding this type of error sources. 
According to the analyses, there weren't any significant differences between the two groups of male and female learners with regard to sources of errors and their types. Namely, although there were more error frequencies in female learners' written productions, the hierarchy of different sources of errors in the two groups of male and female learners was the same.

\subsection{Pedagogical Implications}

Teachers, learners, syllabus designers and researchers benefit from the findings of EA. Teachers can examine the effectiveness of their teaching styles and techniques by studying learners' errors. Additionally, Errors have feedback value and correct diagnosis of error sources helps teachers choose proper sort of treatment (Erdogan, 2005). Error awareness is essential for both teachers and learners. Being aware of the most frequent error types as well as the main error sources, teachers can focus on the learners' linguistic difficulties. Furthermore, they can inform learners about nature of their errors. Making advanced EFL students aware of their most problematic areas can encourage them to concentrate on these errors and improve their writing (Tahririan, 1986). According to Yaghoubi (2009) not only teachers but also learners need some strategies to face the errors so that teachers can correct learners' errors properly and learners can trace their own errors and use proper strategies in the domain of error monitoring and error orientation. Error orientation shows how learners cope with and react to their own errors (Rybowiak, et al., 1999 cited in Yaghoubi 2009). EA contributes to learner-centered language pedagogy by making the teaching techniques closer to the learning strategies, therefore the gap between language learning and teaching can be filled by EA (Mahmoud, 2011).

Considering learners' errors, syllabus designers and material developers can prepare systematic syllabuses and arrange the sequence of materials in the most appropriate way. As Keshavarz (1999) mentioned, they can also provide remedial materials for learners. According to Corder (1967) learners' errors are evidence of a definite language system which show learners' language development at any point. In this regard, EFL/ESL learners' errors can provide important information for researchers about first and second language acquisition and also about the strategies used by a native child or a foreign/second language learner in language learning process. Furthermore, researchers can employ the findings of error-based analyses in other fields of language studies. The same as all EA studies, the findings of the present study can be exploited by teachers, syllabus designers and researchers.

\subsection{Limitations of the study and Suggestions for further studies}

The present study suffers from some limitations. First, the study was limited to a few categories and subcategories for sources of errors, i.e. intralingual errors with three subcategories, interlingual errors with one subcategory, and bi-source errors with no subcategories. Second, the number of participants was limited. Third, the results of the study were based on errors extracted from participants' writing papers, while the rate of their productivity might vary in different situations and at different times; Therefore repetition of the same study with more participants is suggested. Such gender-based error analyses can be re-conducted on students' oral/written productions at elementary and intermediate levels. Some studies can contrast sources of EFL learners' oral/written errors, at different proficiency levels. Effectiveness of different learning strategies as well as teaching methods and techniques can be investigated with regard to types/sources of errors at different proficiency levels. Additionally, gender differences can be considered in such studies. Sources of errors committed by EFL learners with different mother tongues who study English at the same level, with the same syllabus and under the same teaching methodology can also be examined.

\section{References:}

Abbasi, M., \& Karimnia, A. (2011). An analysis of grammatical errors among Iranian translation students: Insights from interlanguage theory. European Journal of Social Sciences, 25(4), 525-536.

Alhaysony, M. (2012). An analysis of article errors among Saudi female EFL students: A case study. Asian Social 
A quantitative analysis of Iranian EFL learners' sources of written errors

Science, 8(12), 55-66. http://dx.doi.org/10.5539/ass.v8n12p55

Al-Khresheh, M. (2010). Interlingual interference in the English language word order structure of Jordanian EFL learners. European Journal of Social Sciences, 16(1), 105-116.

Al-Shormani, M. Q. (2012). Sources of syntactic errors in Yemeni learners' English compositions: A psycholinguistic analysis. Arab World English Journal, 3(4), 275- 296.

Barzegar, M. (2013). Persian EFL students' error analysis. Asian Journal of Social Sciences \& Humanities, 2(4), 322-334.

Behjat, F., \& Sadighi, F. (2010). Iranian English major students' L2 grammar development: Linguistic threshold hypothesis. The Electronic Journal for English as a Second Language, 13(4), 1-19.

Brown, H. D. (1980). Principles of language learning and teaching (4 ${ }^{\text {th }}$ ed.). Englewood Cliffs, NJ: Prentice-Hall Regents.

Brown, H. D. (1994). Teaching by principles: an interactive approach to language pedagogy. Englewood Cliffs, NJ: Prentice Hall Regents.

Catalán, R. (1997). Terms and definitions of errors in SLA. Bells: Barcelona English Language and Literature Studies, 8, 60-81.

Corder, S. P. (1967). The significance of learners' errors. International Review of Applied Linguistics in Language Teaching (IRAL), 5(4), 161-170. http://dx.doi.org/10.1515/iral.1967.5.1-4.161

Corder, S. P. (1974). Error Analysis: perspectives on second language acquisition. London: Longman.

Dan, H. (2007). On error analysis of English majors' writing from the perspective of interlanguage theory. Unpublished masteral thesis, Huizhou University, China.

Dessouky, S. (1990). Error analysis: A non-stop area of research. Studies in Curricula and Methodology, 8, 146-176.

Dulay, H. C., \& Burt, M. K. (1972). Goofing: an indicator of children's second language learning strategies. Language Learning, 22(2), 235-252. http://dx.doi.org/10.1111/j.1467-1770.1972.tb00085.x

Erdogan, V. (2005). Contribution of error analysis to foreign language teaching. Mersin University Journal of the Faculty of Education, 1(2), 261-270.

Faerch, C., Haastrup, K., \& Phillipson, R. (1984). Learner Language and Language Learning. Clevedon: Multilingual Matters.

Ghafar Samar, R., \& Seyyed Rezaie, S. H. (2006). Analysis of errors made by Iranian English learners in their written productions: A new answer to an old question. Foreign Language Teaching Journal (FLT), 21(80), 59-64.

Kafipour, R., \& Khojasteh, L. (2012). A comparative taxonomy of errors made by Iranian undergraduate learners of English. Canadian Social Science, 8(1), 18-24.

Keshavarz, M. H. (1999). Contrastive analysis and error analysis. Tehran: Rahnama Publications.

Kim, S. (2001). An Error Analysis of college students' writing: Is that really Konglish? Studies in Modern Grammar, 25, 159-174.

Mahmoud, A. (2011). The role of interlingual and intralingual transfer in learner-centered EFL vocabulary instruction. Arab World English Journal, 2(3), 28-47.

Nayernia, A. (2011). Writing errors, what they can tell a teacher? The Modern Journal of Applied Linguistics (MJAL), 3(2), 200-217.

Rabieefar, M., \& Askarzadeh Torghabeh, R. A. (2012, October). Language teaching and Iranian EFL learners: Restrictions in verb selection and errors. Paper presented at the $1^{\text {st }}$ Conference on Language Learning \& Teaching: An Interdisciplinary Approach (LLT-IA), Mashad, Iran. Retrieved November 1, 2013, from http://confbank.um.ac.ir/modules/conf_display/conferences/lit/20.pdf

Rahmani, P., \& Bagherzadeh Kasmani, M. (2012). Contrastive analysis: An investigation of error analysis of Kurdish and Persian speaking students majoring in translation (EFL). Asian Journal of Social Sciences \& Humanities, 1(4), 56-60.

Ramezani, F. (2013). The differences between pre-intermediate and advanced learners' sources of syntactic errors. Elixir Online Journal, Educational Technology, 54A, 12611-12615.

Reishaan, A. K. (2013). The use of tenses in the Iraqi advanced EFL learners' writings: An error analysis. 
Rostami Abusaeedi, A. A. \& Boroomand, F.

Bulletin of the Transilvania University of Brasov, Series IV, No.1: Philology and Cultural Studies, 6(55), 99-116.

Richards, J. C. (1971). A non-contrastive approach to error analysis. In J.C. Richards (Ed.), Error analysis: perspectives on second language acquisition (pp. 172-189). London: Longman.

Ridha, N. S. (2012). The effect of EFL learners' mother tongue on their writings in English. An error analysis study. Journal of the College of Arts, University of Basrah, 60, 22-45.

Rostami Abusaeedi, A. A., \& Shariati, M. (2003). New linguistic issues. Zahedan: The University of Sistan and Baloochestan Press.

Rybowiak, V., Garst, H., Frese, M., \& Batinic, B. (1999). Error orientation questionnaire (EOQ): Reliability, validity, and different language equivalence. Journal of Organizational Behavior, 20, 527- 547. http://dx.doi.org/10.1002/(SICI)1099-1379(199907)20:4<527::AID-JOB886>3.0.CO;2-G

Sabzalipour, B. (2012). Error analysis on students' Persian-English translation. Asian Journal of Social Sciences \& Humanities, 1(4), 71-76.

Şanal, F. (2007). A Learner Based Study on Second Language Lexicology of Turkish Students of English. Unpublished doctoral dissertation, Cukurova University, Turkey.

Sattari, A. (2012). An analysis of grammatical errors in Iranian students' English writings. Iranian EFL Journal, 8(2), 143-157.

Selinker, L. (1972). Interlanguage. International Review of Applied Linguistics in Language Teaching (IRAL), 10(3), 209-231. http://dx.doi.org/10.1515/iral.1972.10.1-4.209

Sheikhzadeh, E., \& Gheichi, M. (2011). An account of sources of errors in language learners' interlanguage. International Proceedings of Economics Development \& Research (IPEDR), 26, 159-162.

Shreshta, N. (1979). Error analysis: A pragmatic approach. Contributions to Nepalese Studies (CNAS Journal), VI(2), 1-9.

Tahririan, M. H. (1986). Error awareness and advanced EFL learner's performance. Regional Language Centre (RELC) Journal, 17(2), 41-54.

Tajadini Rabori, M. (2006). Error detection as a device towards the investigation and elaboration of Interlanguage. Journal of social sciences \& humanities of Shiraz University, 23(1), 91-106.

Taylor, B. P. (1975). Adult language learning strategies and their pedagogical implications. Teachers of English to Speakers of other Languages (TESOL) Quarterly 9(4), 391-399.

Taylor, G. (1986). Errors and explanations. Applied Linguistics, 7(2), 144-166. http://dx.doi.org/10.1093/applin/7.2.144

Wee, R. (2009). Sources of errors: An interplay of interlingual influence and intralingual factors. European Journal of Social Sciences, 11(2), 349-359.

Yaghoubi, A. (2009). Error competence and structural competence in EFL context. The Journal of Modern Thoughts in Education, 4(4), 91-110.

Yazdani, P., \& Ghafar Samar, R. (2010). Involved or informative: A gender perspective on using pronouns and specifiers in EFL students' writing. The Modern Journal of Applied Linguistics (MJAL), 2(5), 354-378. 